\title{
水文資料がそしい地域における流出解析法
}

A Study on the Determination of Runoff without Reffering to the Sufficient Hydrologic Data

1. はじめに

$\begin{array}{ll}\text { 長崎大学工学部 } \bigcirc \text { 野口正人 } \\ \text { 長崎大学大学院 } \\ \text { 日本道路公団 } & \text { 倉広幸 } \\ \text { 菅 浩- }\end{array}$

長崎市では、昭和57年 7月豪雨による被害を蒙ったが、いまでは市内河川の改修もかなり進んでいる。わ れわれは、長崎災害以後 2 年間余、水防災システムに関する研究を続けてきたが、これも長崎が豪雨災害に対 して強い都市になることを願っているからにほかならない。一般に、水防災システムを完備していくにあたっ て、流出解析がその滛矢として重要なことは声を俟たない。そのため、これまでにも多数の流出解析法が提案 され、大河川等においては、かなりの精度で洪水時の流出量を予湘することが可能となった。しかし、流出解 析モデルを適用する場合、往々にして、集中定数型モデルのパラメーター選定、ないしは、分布定数型モデル における流出機構の普迡化に困難を伴うことはよく知られている。とりわけ、中小河川においては水文観測も 十分に行われておらず、問題を一層䙓雜にしている。

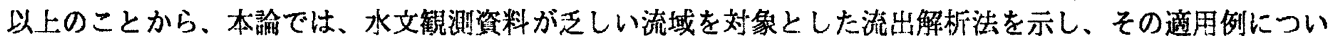
て報㪇する。

\section{2. 流出解析モデル}

\section{1 変形雨水流法}

前述されたように、水文资料がそしい地域でさえ、しばしば流出解析をせねばならない。とくに、流出解 析結果の精度を高めようとすれば、分布定数型モデルが適しているが、流域システムをあまりに細分化するこ とは、実用上好ましくない。したがって、以下に示すモデルでは、表面流を雨水流法で表畋するとともに、土 中への浸透量を考虑し、洪水流量に関与するその他の成分 をタンクモデルで表した（図-1、参照）。すなわち、急 傾斜地流域における表面流出成分は、つぎの基礎方程式で 表現される。

$$
\begin{aligned}
& \frac{\delta h}{\delta t}+\frac{\delta q}{\delta x}=r-i \\
& h=k q^{p}
\end{aligned}
$$

ここに、 $\mathrm{h}$ : 表面流の水深、 $\mathrm{q}$ : 単位幅流量、 $\mathrm{r}$ : 有効降雨 強度、 i : 浸透量である。通常、上式中の浸透量は、Horton ないしは Philip の浸透能式で評価される。しかし、 初期浸透能や最終浸透能が、流域の湿润状態あるいは地形・ 地質・植性等の流域特性量により変化するため、それらと

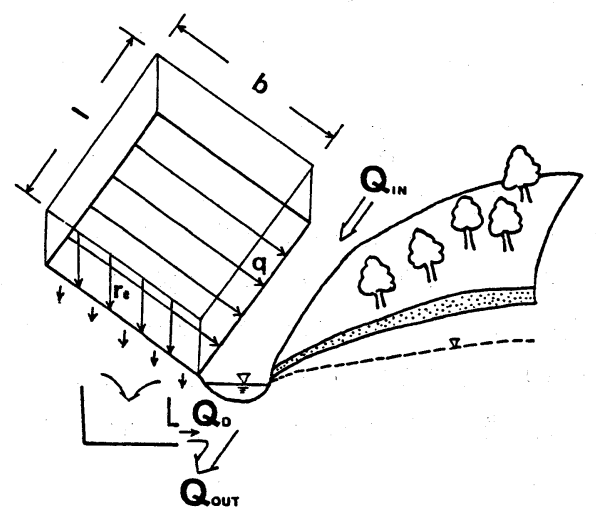

図一 1 流出モデルの概念図

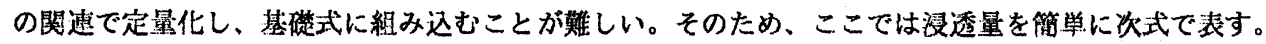

$$
\mathrm{i}=\mathrm{ch}
$$

もちろん、浸透量を上式のように表現し得るか否かは問題があるが、係数 c を変数と見做して、流域諸量より 評価することとする。

つぎに、洪水流出に直接関与する中間流出成分を求めるため、前述の浸透量をタンクへの入力として取り扱 う。一般に、洪水流出量をタンクモデルで求める場合、3〜4段のタンクが用いられるが、水文资料が整って いない段階では、流出孔ならびに浸透孔の乗数を決めることができない。もっとも、ここで示されたモデルで 
は、表面流出成分は別に扱われているので、第 1 次近似として1段タンクを用いることも、さほど無理ではな

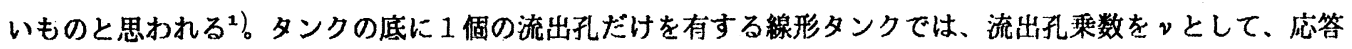
関数は次式で表される。

$$
K(t)=v e^{-v t}
$$

ここに、乗数 $山$ は流量隇㐮曲線より求められる。

\section{2 計算手法}

計算は、斜面流ならびに河道流のそれぞれについて行い、土中への浸透は山腹斜面のみで考虑することと した。このとき、河道流は雨水流で計算することができ、斜面流についても、基礎方程式を特性曲線法により 解くことができる。すなわち、(1)式を書き改めれば、つぎのようになる。

$$
\mathrm{dx}=\frac{\mathrm{dt}}{\mathrm{dh} / \mathrm{dq}}=\frac{\mathrm{dq}}{\mathrm{r}-\mathrm{i}}
$$

(2)、（3）式を考虑すれば、結局、次式を得る。

$$
\begin{aligned}
& \frac{\mathrm{dx}}{\mathrm{dt}}=\frac{1}{\mathrm{pkq}-1} \\
& \left(\mathrm{r}-\mathrm{ckq}^{\mathrm{p}}\right) \mathrm{dt}=\mathrm{pkq}^{\mathrm{p}-1} \mathrm{dq}
\end{aligned}
$$

したがって、特性曲線の位置ならびにその上での流量は、以下のように差分表示される。

イ) $\mathrm{r}_{\mathrm{j}}-\mathrm{ckq} \mathrm{p}-1 \neq 0$ のとき

$$
\begin{aligned}
q_{j} & =\left[\frac{r_{j}-\left(r_{j}-c k q \frac{p}{j}-1\right) e^{-c \Delta t}}{c k}\right]^{\frac{1}{p}} \\
& \simeq\left[q_{j-1}^{p}+\frac{r_{j}-c k q}{k}-1\right]^{\frac{1}{p}} \\
\Delta x_{j} & =\frac{q_{j}-q_{j-1}}{r_{j}-c k q_{j-1}^{p}}
\end{aligned}
$$

ㅁ) $r_{j}-c k q_{j-1}^{p}=0$ のとき

$$
\begin{aligned}
q_{j} & =q_{j-1} \\
\Delta x_{j} & =\frac{1}{p k q_{j-1}^{p}} \Delta t
\end{aligned}
$$

ただし、上式中の $\Delta t$ 計計算時間間隔であり、添字の $\mathrm{j}$ は、初期時刻より $j \Delta t$ 時間後の值であることを示し ている。以上の諸式により演算を進める場合、流れが下流端に到達する端数時間の計算や、特性曲線が他の特 性曲線を追い抜く際の処理等が必要であるが、これらは雨水流法の場合と同様にして取り扱える2)。

つぎに、斜面流の浸透成分はタンクモデルを使って計算されるが、タンクは1段線形のものであるため、遅 れ時間が考虑されない。そのため、対象小流域の流路長ならびに中間流の流速より遅れ時間を求めることとし た。なお、タンクモデルからの流出量を匢り扱う力法としては、流出量を斜面流の途中で考虑する力法と、河 道への横流入量として考慮する方法の 2 種類が考えられる。前者の方法で合理的に計算を行うためには、対象 流域の水みちを詳細に楛查することが必要であり、実用的流出解析法としては適当でない。そのため、ここで は、タンクモデルからの流出量を、刘象小流域に接する河道への横流入量とした。

上述されたように、流出計算は、基準地点での流域を小流域に分割して行われるが、ダムが标在する場合に は、貯水量を次式で計算する。

$$
\frac{d V}{d t}=Q_{u}+\left(q_{1}+q_{r}\right) 1+r A-Q_{d}
$$

ここに、 $\mathrm{V}$ : 眝水池水量、 $\mathrm{A}$ : 眝水池水平面面積、 $1:$ 眝水池长さ、 $\mathrm{r}:$ 降雨強度、 $\mathrm{Q}_{\mathrm{u}}, \mathrm{Q}_{\mathrm{d}}$ :それぞれ、上・ 
下流端の流量、 $\mathrm{q}_{\ell}, \mathrm{q}_{\mathrm{r}}$ :それぞれ、左右岸から盯水池への単位幅流入量である。なお、上式中の $Q_{\mathrm{d}}$ は、放 流工の形状がわかれは、越流水深を使って求められる。

\section{3. 浦上川の流出解析}

前節で示された変形雨水流法を用いて、水文資料がそしい地域での流出解析を行うため、以下では、長崎 市内河川の浦上川を取り举げて检㑏する。

\section{1 浦上川の概要}

浦上川は、図ー2に示されたように、多良見町 に近い畘別当付近より発し、長崎港に注いでおり、 全流域面積：38.1 km、流路延辰： $13.3 \mathrm{~km}$ の 2 級河川 である。この川は、長崎市ならびに周辺町村の河川 の中にあって、流域面積、流路延長ともに最も大き く、長崎市にとって重要な都市河川である。長崎豪 雨の際には、中島川と同じく溢水・沉濫し $、 大$ 大きな 社会問題となった。そのため、浦上川の高水計画に 関しても見直しを迫られたが、十分な水文観湘凟料 が無いため、容易には洪水流量を呯伍できないのが 実状であった。なお、浦上川の支川である大卦手川 が本川と合流する地点には、長崎市民の水がめの一 つである浦上眝水池があるが、この眝水池について

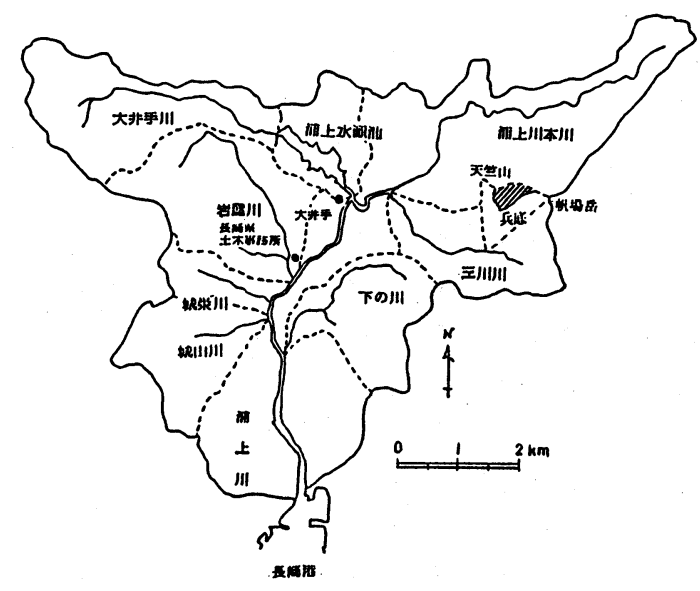

园-2 浦上川流域の概念図

も、利水専用から一部治水用に振り替えることが計画されている。

\section{2 計算結果と考察}

ここでは、変形雨水流法により大井手地点での流出量を求め、結果 の妥当性について検討する。一般に、流出計算をする場合、対象流域を どの程度まで小さく分割するかを決めなければならない。これは、その 地域の降雨が降雨観湘点のもので代表される堨の尺度や、流域地形によ って変ってくるものと思われる。ただ、われわれが他の河川で流出解析 を行ったときの経験から言えば、後者については、さほど局所的な地形 の違いを考虑しなくても良いようである。以上のことから、支川流域ご とに流出計算を行うこととし、流域を浦上川上流、三川川、大井于川、 ならびに浦上水源池の各ブロックに分割した。計算は、各ブロックの右

\section{表 -1 流域諾量}

\begin{tabular}{|c|c|c|c|c|}
\hline & & 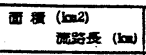 & 平均的㫜 & 酷化现 \\
\hline $\begin{array}{l}\text { 严 } \\
\text { 点 } \\
\text { 高 }\end{array}$ & 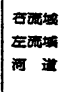 & $\begin{array}{l}3.13 \\
4.85 \\
7.80\end{array}$ & $\begin{array}{l}0.472 \\
0.377 \\
0.032\end{array}$ & $\begin{array}{r}12.0 \\
5.7\end{array}$ \\
\hline $\begin{array}{l}\text { III } \\
\text { III }\end{array}$ & 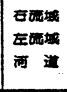 & $\begin{array}{l}2.13 \\
1.11 \\
3.47\end{array}$ & $\begin{array}{l}0.426 \\
0.557 \\
0.071\end{array}$ & $\begin{array}{l}15.3 \\
40.4\end{array}$ \\
\hline $\begin{array}{l}\text { 奔 } \\
\text { 艒 } \\
\text { i! }\end{array}$ & 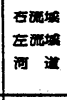 & $\begin{array}{l}3.28 \\
1.72 \\
4.55 \\
\end{array}$ & $\begin{array}{l}0.378 \\
0.289 \\
0.027 \\
\end{array}$ & $\begin{array}{l}48.2 \\
65.7\end{array}$ \\
\hline 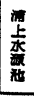 & 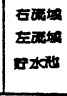 & $\begin{array}{l}0.28 \\
2.11 \\
1.43\end{array}$ & $\begin{array}{l}0.378 \\
0.289 \\
0.047\end{array}$ & $\begin{array}{l}48.2 \\
65.7\end{array}$ \\
\hline
\end{tabular}
流域、左流域、河道、もしくは眝水池に対して行うものとする。各要素の諸元は、表一1にまとめられている。

つぎに、変形雨水流法で計算を行うためには、各種のパラメーターを決定しなければならない。表面流につ いては、流れの抵抗則を Manning型で表見することにすれは、 $\mathrm{p}=0.6 、 \mathrm{k}=(\mathrm{N} / \sqrt{\mathrm{I}})^{\mathrm{p}}$ となる。ただし、 $\mathrm{N}$ : 等価粗度係数、I : 斜面こう配、である。一方、タンクの乗数について調べるため、昭和58年梅雨期の観測資 料を用いて、流量隇衰曲線を片対数綎上に表せば、図一3のようである。これより、減哀俰数 $0.03 \mathrm{~min}^{-1}$ となり、若干の幅がある。これは、7月 5日の降雨に対する流出は、それ以前に暫く雨が降ってい ないことによる影響を受けたのに対し、7月16，17日のものは、そうでないことによっている。そのように考 えれは、詳細な流出解析に対しては、1 段タンクは適当でないようにも思える。参考までに、本明川・锥山地 点における同種の図を、図ー4として示した。この図では、浦上川の場合とは反対に、減衰係数がほぼ一定に なっているが、その理由は上述されたことから明らかである。したがって、2.1にも述べられたように、第 1次近似として、1段タンクを用いることは妥当であろう。 


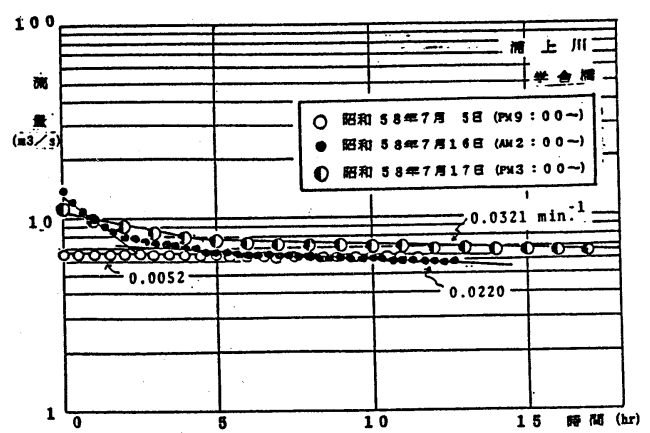

図-3 流量墄水曲線 (浦上川,学舎橋)

以上のようにして求められた、昭和57年 7月 23〜24日ならびに昭和58年.7月15〜17日のハイ ドログラフが、図ー5、図ー6に示されている。 計算にあたって係数 $\mathrm{c}$ は $0.25 \mathrm{hr}^{-1}$ としたが、こ れについては後述する。等価粗度係数Nは、山 地等で 1.0 , 市街地で $0.04 \mathrm{sec} / \mathrm{m}^{\frac{1}{3}}$ とし 2 、対象流 域の市街化率より平均值を求めた。図一 5 から 明らかなように、長崎豪雨時の流显ハイドログ ラフの立ち上がりは極めて急峻であり、長崎の 如き急傾斜斜面都市における水防災対策の困難 さを窥わせる。図中には、中安の総合単.位図法 4)により求められた計算結果も示されている。 両手法による計算結果を比較するには実测資料 がそしいが、われわれが災害直後に浦上橋で夷 湘した值、ならびに、浦上䠉水池の水位から流 量を求め流域面積率により学舎橋のものに変換 した值を参照すれば、本手法の有効性が知れる。

一方、図一6において、c $=0.25 \mathrm{hr}^{-1}$ とした 変形雨水流法の結果を実湘値と比較すれば、減 水期における流出現象がよく表現されているこ とがわかる。ところが、ピーク付近で計算值は 実測値をかなり下まわっている。これは、一つ には、実測流量と称するものが、水位一流量曲 線を使って実測水位より求められた流量である こと、さらには、 $\mathrm{c}$ の值を一定にしたためであ ると思われる。・方、単位对法による結果は、 上述のものと反詨の傾向にあり、変形雨水流法 で c を小さくした結果とよく似ている。これは、 単位図法では、雨水が土中へ浸透する影響を無 視しているためである。

以上述べられたことから明らかなように、変

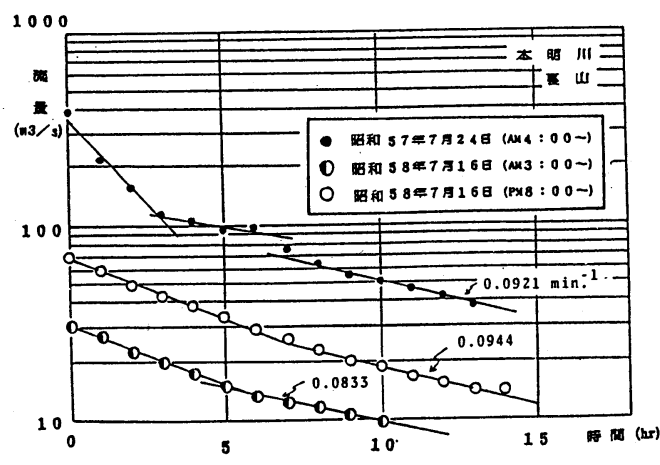

図-4 流量隇水曲線(本明川,軎山)

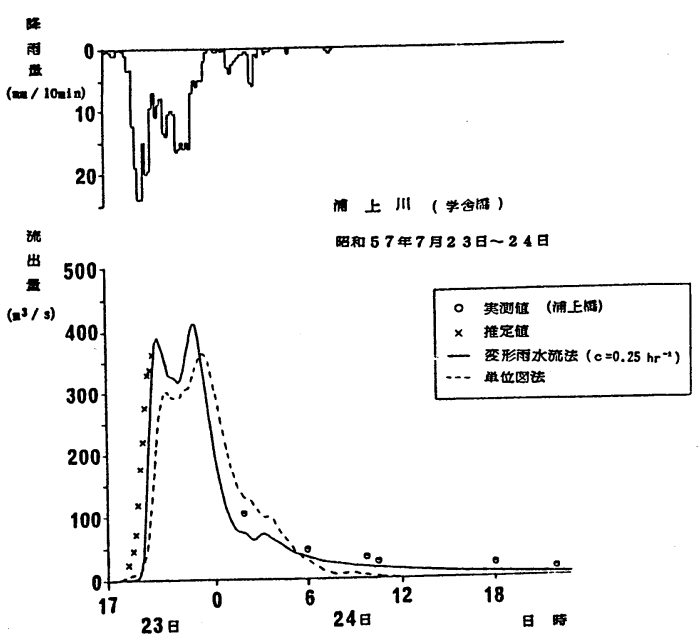

図ー5 流星ハイドログラフ(昭和57年7月23 24日)

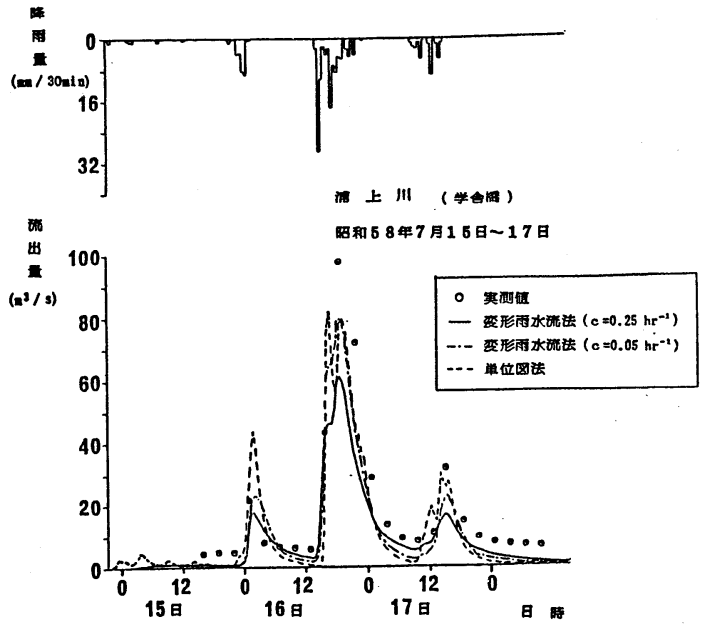

図-6 流星ハイドログラフ（昭和58年7月15 17日） 
形雨水流法は、短期・長期の別なく流出解析に供せられる。もちろん、艮期流出解析を行う場合には、最低 2 段のタンクを用意するとともに、蒸登量についても考慮せねばならないことは当然である。また。本手法によ り流出量を精度良く求めるためには、土中浸透量や中間流の速度を正しく評価せねばならぬことは言うまでも ない。

4. 浦上川武験流域での水文観測

4.1 水文钼測の概要

层崎凉雨災害時の菬い経験から、 早急な水防災システムの整備が望まれ るが、そのためにも、水文観測は久か せない。このようなことから、昭和 58 年 6月に大井手地点の学舎橋に水位計 を設置し観測を続けている。また、昭 和59年 9 10月には、图一 2 の斜線部 分で示された兵底地域で、雨量・河川! 水位・士壤水分等の水文観測を行った。

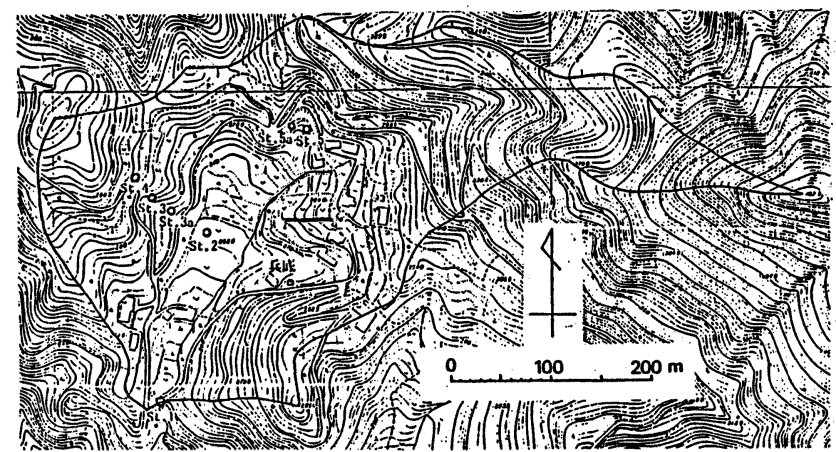

図-7 水文镜測対象流域(兵底) この観測は、昭和60年度以降も 梅雨期に実施される予定である が、 4.2 では、変形雨水流法

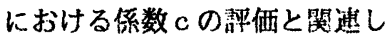
て土中浸透量について簡単に触 れる。

水文観測を行った兵底地域は、 浦上川支川の三川川の上流に位 置している(図-7)。本地域の 袁層地貿は、主に閃緑岩・変朽 安山岩から成っている5゙。この 付近は、三川川沿いの三川町と 異なり、全く市街化されておら ず、民家は十戸を数える程度で ある。長崎豪雨の際には、天䇥 山西侧斜面で川平の土石流が発 生しているが、この地域では、

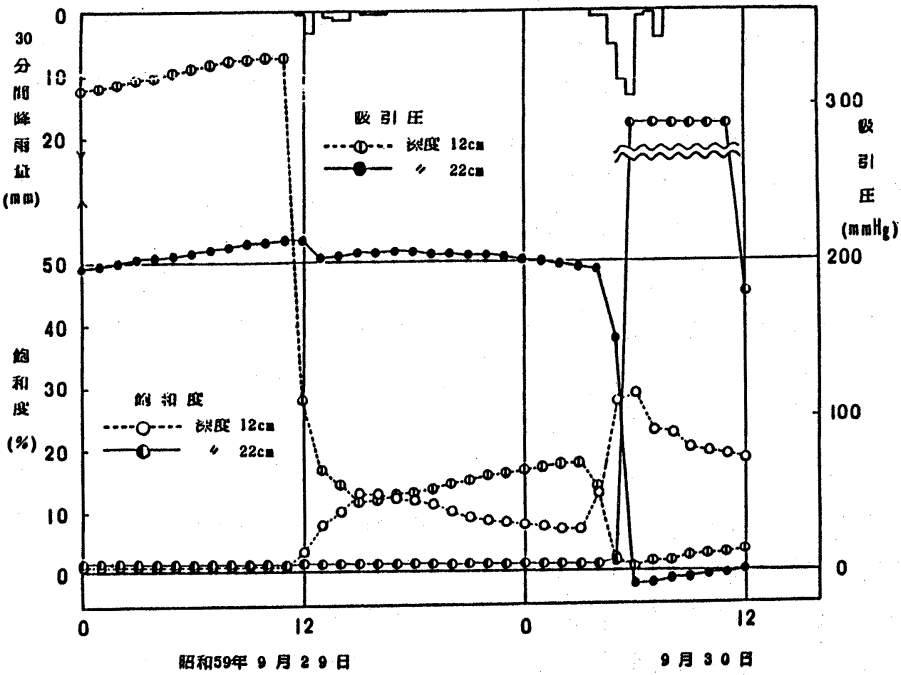

図-8 吸引圧と飽和度の時間的変化 小規模な土砂崩壊を除き、大きな被害を受けていない。なお、この近くに国鉄長崎本線の長崎トンネルがある ため、以前には常時流れていた川も、現在では、降水時にしか水を湛えなくなった。筧剆は、主として、雨量 （転倒ます型雨量計）、土壤水分、河川水位(フロート式自記水位計)について行われた。土壕水分は自記テンシ

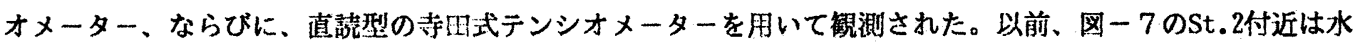

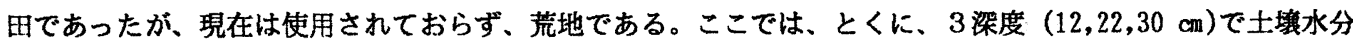
を揤定した。観測は前述の期間に行われたが、昭和59年は例年になく台風の少ない年で、この期間中、さほど 大きな降雨は無かった。したがって、土中における水の挙動について考察するには資料不足であり、次小節で は土中瀑透量のみを取り举げた。 


\section{2 観測結果の考察}

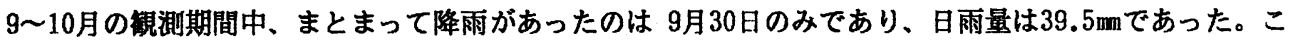
こでは、このときの資料をもとに雨水の土中浸透量を求め、cの大きさに関して述べる。

まず、9月29〜30日について、降雨量ならびにSt.2の吸引圧を示せは、図ー8のようである。この図より明 らかなように、29日の10m程度の雨では、その影響はこく表層付近に限られているが、30日の前述の降雨では、 雨水が土中梁くに浸透していることがわかる。参考までに、深度 $30 \mathrm{~cm}$ の吸引圧はほほ零であった。いずれの雨 でも、降雨開始とともに、深度 $12 \mathrm{~cm}$ の土㙥水分は即 座に変化している。したがって、深度 $12 \mathrm{~cm}$ と $22 \mathrm{~cm} の$ 土壤水分を使って雨水の降下速度を計算すれは、 5 $\sim 8 \times 10^{-3} \mathrm{~cm} / \mathrm{s}$ であった。ところで、土中浸透量を 求めるためには、吸引压と䭂和度の関係を知らねば ならない。そのため、钼湘点の土塊を原形のま〉採 取し、表面を飽和させた室内実験を行った。図一 9 には、このときの土表面での水分フラックスが示さ れており、初期浸透能は $3.5 \times 10^{-3} \mathrm{~cm} / \mathrm{s}$ であった。 土表面の水は、平面的に一様に降下せず、時間が経

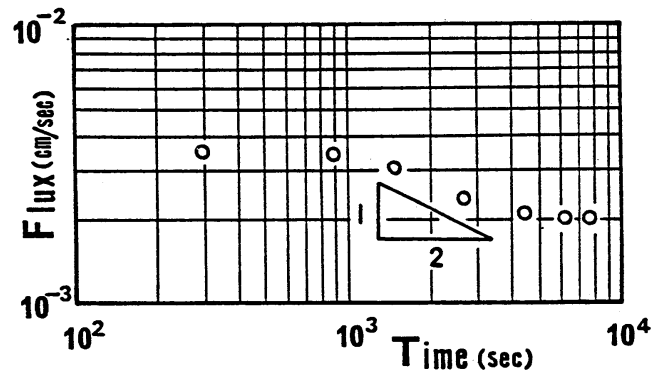

図一 9 土表面の水分フラックス 過してからも間鵪を满たす補償流があり、フラックスは理論通り-1/2のこう配で減少しない。これは水分浸透 の容易さの違いから生ずるものである。実験結果から土辕水分の拡散係数を計算すれば、概略 $5 \times 10^{-2} \mathrm{~cm}^{2} / \mathrm{s}$ であった。図ー8には、実験で求められた吸引匤と飽和度の関係を用いて換算した飽和度の值も示されている。 St.2の詳細な土壤水分鉛直分布が钼測されていないため、30日の雨に対する土中浸透量を求めることができな いが、以上の諸量から判断して、実験室で得られた浸透能に近い值であることが推定できる。

上述されたことから、三川川の右流域で求めた $\mathrm{c}$ の值は $0.1 \sim 1 \mathrm{hr}^{-1}$ のオーダーである。実際の水文現象と 対比させた場合、(3)式のように置くことは非常に問題があるが、実用的モデルとして流出量を計算する際に 土中浸透の影響を考虑し易いことは、2.でも述べられた通りである。

\section{5. まとめ}

本論文では、水文资料がそしい地域を対象とした流出解析法として変形雨水流法を提案し、その適用上の 妥当性について梌討した。今後、さらに、降雨時の土中浸透量について検討せねはなならないが、対像流域で十 分な水文钼湘資料がないときにも、地形・地質・植性等の違いを考慮した流出計算をし得るものと思われる。 （謝辞）本研究では、昭和59年度文部省自然災害特別研究（代表 : 伊勢田哲也長崎大学教授）の補助を受けた ことを記し、謝意を表します。また、水文観測の実施にあたっては、是崎大学工学部土木工学科の平山康志技 官、学部学生の森尾宣紀君らの協力を得た。併せて感謝致します。

\section{※ 参考文献}

1）野口正人・小林高昌・山本隆洋；流出タンクモデルの同定に関する研究，長崎大学工学部研究報告,第17号, 昭和56年

2）角屋睦；講座 流出解析法,農業土木学会誌,第 47 巻10号～第49巻6号,昭和54～56年

3）野口正人・中村武弘·平山康志·武田篤；長崎市街地の河川氾監，昭和57年 7月豪雨による災害の調查報告書, 脣䗁大学学術調查団, 昭和 57 年

4）建設省河川局,日本河川協会；建設省河川砂防技術基準(案),調查編, 山海堂,昭和51年

5）長崎県；土地分類基本調查一長崎一,昭和48年 